\title{
Pemisahan Unsur-unsur pada Monasit Bangka dengan Pengendapan Bertingkat
}

\author{
Separation of Elements in Bangka Monazite \\ with Multilevel Precipitation
}

\author{
Anggi Novriyanisti ${ }^{1}$, Riesna Prassanti2 ${ }^{*}$, Kurnia Setiawan Widana ${ }^{2}$ \\ ${ }^{1}$ Program Studi Kimia, Fakultas Sains dan Teknologi, Universitas Islam Negeri Syarif Hidayatullah Jakarta \\ Jl. Ir. H. Juanda No. 95, Cemp. Putih, Kec. Ciputat Tim., Kota Tangerang Selatan, Banten, Indonesia, 15412 \\ ${ }^{2}$ Pusat Teknologi Bahan Galian Nuklir-BATAN \\ J1. Lebak Bulus Raya No. 9, Ps. Jumat, Jakarta, Indonesia, 12440 \\ *E-mail: riesna@batan.go.id
}

Naskah diterima: 10 November 2020, direvisi: 15 April 2021, disetujui: 22 April 2021

DOI: 10.17146/eksplorium.2021.42.1.6093

\begin{abstract}
ABSTRAK
Monasit merupakan mineral hasil samping pengolahan timah yang memiliki kandungan utama unsur uranium (U), torium (Th), logam tanah jarang (LTJ), dan senyawa fosfat $\left(\mathrm{PO}_{4}\right)$. Di samping unsur-unsur utama tersebut, monasit juga mengandung logam-logam lain seperti aluminium (Al), besi (Fe), bismut (Bi), galium ( $\mathrm{Ga})$, dan talium (Tl). Unsur-unsur pada monasit harus dipisahkan agar dapat dimanfaatkan. Penelitian ini bertujuan untuk mengetahui pengaruh variasi $\mathrm{pH}$ dalam pemisahan unsur-unsur pada monasit dengan pengendapan bertingkat serta menentukan unsur apa saja yang dihasilkan dari setiap variasi $\mathrm{pH}$. Variasi $\mathrm{pH}$ yang digunakan dimulai dari $\mathrm{pH}$ 0,5 sampai 10 dengan selisih antar-pH sebesar nol koma lima. Unsur-unsur dalam monasit dipisahkan secara bertahap dimulai dari proses dekomposisi menggunakan natrium hidroksida $(\mathrm{NaOH})$, pelarutan dengan asam klorida $(\mathrm{HCl})$, dan pengendapan bertingkat dengan amonium hidroksida $\left(\mathrm{NH}_{4} \mathrm{OH}\right)$. Unsur dianalisis menggunakan instrumen Inductively Coupled Plasma Optical Spectroscopy (ICP-OES) dan Spektrofotometer UV-Visible. Pengaruh variasi $\mathrm{pH}$ menghasilkan endapan pada $\mathrm{pH} 3, \mathrm{pH} \mathrm{6,} \mathrm{pH} \mathrm{6,5,} \mathrm{dan} \mathrm{pH}$ 7. Unsur yang dihasilkan pada setiap variasi $\mathrm{pH}$ adalah uranium, torium, logam tanah jarang, aluminium, besi, bismut, galium, dan talium. Uranium dan torium paling banyak berada pada endapan $\mathrm{pH} 3$ dengan recovery $\mathrm{U} 72,3 \%$ dan $\mathrm{Th}$ $46,33 \%$ serta logam tanah jarang pada $\mathrm{pH} 6,5$ dengan recovery 41,87\%. Unsur $\mathrm{Fe}$ dan Bi paling banyak mengendap pada pH 3 dengan kadar 37,9 ppm dan 100,9 ppm. Unsur Al, Ga dan Tl paling banyak mengendap pada pH 6,5 dengan kadar 30,2 ppm, 69,8 ppm, dan 8 ppm.
\end{abstract}

Kata kunci: monasit, pengendapan bertingkat, torium, uranium, logam tanah jarang, $\mathrm{NH}_{4} \mathrm{OH}$

\begin{abstract}
Monazite is a mineral side product of tin processing, which mainly contains uranium $(U)$, thorium (Th), rare earth elements (REE), and phosphate compounds $\left(\mathrm{PO}_{4}\right)$. Besides these main elements, monazite also contains other metals such as aluminum ( $\mathrm{Al})$, iron ( $\mathrm{Fe})$, bismuth (Bi), gallium ( $\mathrm{Ga})$, and thallium (Tl). The elements in monazite must be separated to be used. This study aims to determine the effect of $p H$ variations in the separation of components in monazite with multilevel precipitation and determine elements produced from each $\mathrm{pH}$ variation. The variation $\mathrm{pH}$ starts from $\mathrm{pH} 0,5$ to 10 with a different $\mathrm{pH}$ of zero points five. The elements in monazite are separated gradually, beginning from the decomposition process using sodium hydroxide (NaOH), dissolving with hydrochloric acid $(\mathrm{HCl})$, and graded deposition with ammonium hydroxide $\left(\mathrm{NH}_{4} \mathrm{OH}\right)$. The elements were analyzed using the instrument Inductively Coupled Plasma Optical Spectroscopy (ICP-OES) and $U V$-Visible Spectrophotometer. The effect of $p H$ variations produced precipitated $p H 3, p H$ 6, pH 6.5, and pH 7. The elements produced at each $\mathrm{pH}$ variation are uranium, thorium, rare earth elements, aluminum, iron, bismuth, gallium, and thallium. Uranium and thorium were mostly at $\mathrm{pH} 3$ with the recovery of $U 72.3 \%$ and $\mathrm{Th} 46.33 \%$ and rare earth elements at pH 6.5 with $41.87 \%$ recovery. The elements Fe and Bi mostly settle at pH 3 with levels
\end{abstract}


of 37.9 ppm and $100.9 \mathrm{ppm}$. The elements $\mathrm{Al}, \mathrm{Ga}$, and $\mathrm{Tl}$, precipitate most at pH 6.5 with grades of 30.2 ppm, 69.8 ppm, and 8 ppm respectively.

Keywords: monazite, multilevel precipitation, thorium, uranium, rare earth elements, $\mathrm{NH}_{4} \mathrm{OH}$

\section{PENDAHULUAN}

Monasit merupakan mineral hasil samping pengolahan timah yang memiliki kandungan unsur uranium (U), torium (Th), logam tanah jarang (LTJ), dan fosfat $\left(\mathrm{PO}_{4}\right)$. Persentase banyaknya masing-masing unsur penyusun monasit antara lain $\mathrm{LTJ}_{2} \mathrm{O}_{3} 58,97 \%$, U 0,298\%, Th 4,147\%, dan $\mathrm{PO}_{4} 23,712 \%$ [1]. Selain unsur-unsur utama tersebut, monasit juga mengandung unsur-unsur minor seperti aluminium (Al), besi (Fe), bismut (Bi), galium $(\mathrm{Ga})$, dan talium ( $\mathrm{Tl})$. Berbeda dari unsur-unsur utama, kadar unsur-unsur minor tersebut pada monasit cenderung kecil $(<100$ ppm) sehingga dianggap sebagai pengotor. Keberadaan unsur-unsur tersebut pada monasit masih bercampur antara satu dengan lainnya sehingga harus dipisahkan melalui proses kimiawi untuk dapat dimanfaatkan sesuai kegunaannya masing-masing.

Proses pemisahan unsur-unsur U, Th, LTJ, dan fosfat dari bijih monasit dapat dilakukan dengan metode asam menggunakan $\mathrm{H}_{2} \mathrm{SO}_{4}$ [2] dan metode basa menggunakan $\mathrm{NaOH}$ [3]. Tahapan proses yang dihasilkan dengan metode basa antara lain dekomposisi, pelarutan parsial $(\mathrm{pH} 3,7)$, pengendapan $U$ dan Th (pH 6,3), serta pengendapan LTJ ( $\mathrm{pH}$ 9,8 ) [2]. Dari proses ini unsur yang terpisah hanya unsur utama pada monasit, yaitu $\mathrm{U}, \mathrm{Th}$, dan LTJ sedangkan unsur-unsur minor akan terikut pada unsur utama yang telah terpisah sehingga menurunkan kemurnian produk. Untuk meningkatkan kemurnian produk maka unsur pengotor harus dipisahkan dari unsur utama. Salah satu cara untuk pemisahan unsur dari mineral adalah dengan pengendapan bertingkat. Pada proses ini, tiap-tiap unsur akan mengendap berdasarkan kelarutannya pada kondisi $\mathrm{pH}$ tertentu.

Penelitian ini dilakukan dengan melaksanakan proses pengendapan bertingkat untuk mengetahui pengaruh variasi $\mathrm{pH}$ dalam mengendapkan unsur-unsur pada monasit serta menentukan unsur apa saja yang dihasilkan dari setiap variasi $\mathrm{pH}$. Adapun bahan kimia yang digunakan sebagai reagen pengendap adalah $\mathrm{NH}_{4} \mathrm{OH}$. Penggunaan $\mathrm{NH}_{4} \mathrm{OH}$ ini tidak akan mengotori endapan karena $\mathrm{NH}_{3}$ mudah menguap [4].

\section{TEORI}

Monasit merupakan mineral fosfat yang mengandung logam tanah jarang, torium, dan uranium [5]. Mineral ini jika diolah secara kimiawi akan menghasilkan garam unsur $\mathrm{U}$, Th, logam tanah jarang, dan fosfat. Rumus kimia monasit secara umum adalah (LTJ, Th, U) $\mathrm{PO}_{4}$ [6]. Unsur yang terkandung dalam monasit memiliki nilai ekonomisnya masingmasing. Logam tanah jarang digunakan dalam bidang industri, metalurgi, dan kimiawi [5]. Uranium dan torium sebagai bahan bakar reaktor nuklir [7].

Pembuatan umpan pengendapan bertingkat diawali dengan proses dekomposisi untuk memisahkan fosfat, dimana senyawa fosfat pada monasit diubah menjadi senyawa hidroksida dengan reagen sodium hidroksida $(\mathrm{NaOH})$. Reaksi yang terjadi pada proses dekomposisi adalah sebagai berikut [1]:

$$
\begin{aligned}
& \mathrm{LTJ}\left(\mathrm{PO}_{4}\right)(\mathrm{s})+3 \mathrm{NaOH}(\mathrm{aq}) \rightarrow \mathrm{LTJ}(\mathrm{OH})_{3}(\mathrm{~s}) \\
& +\mathrm{Na}_{3} \mathrm{PO}_{4} \downarrow \\
& \mathrm{Th}_{3}\left(\mathrm{PO}_{4}\right)_{4}(\mathrm{~s})+12 \mathrm{NaOH}(\mathrm{aq}) \rightarrow 3 \mathrm{Th}(\mathrm{OH})_{4}(\mathrm{~s}) \\
& +4 \mathrm{Na}_{3} \mathrm{PO}_{4} \downarrow
\end{aligned}
$$


$\left(\mathrm{UO}_{2}\right)_{3}\left(\mathrm{PO}_{4}\right)_{2}+6 \mathrm{NaOH} \rightarrow 3 \mathrm{UO}_{2}(\mathrm{OH})_{2}+2$

$\mathrm{Na}_{3} \mathrm{PO}_{4} \downarrow$

Selanjutnya, endapan (U, Th, LTJ) hidroksida dilarutkan dengan asam kuat seperti $\mathrm{HCl}, \mathrm{H}_{2} \mathrm{SO}_{4}$, dan $\mathrm{HNO}_{3}$. Hasil pelarutan dengan $\mathrm{H}_{2} \mathrm{SO}_{4}$ maupun $\mathrm{HNO}_{3}$ yang rnenghasilkan larutan (U, Th, LTJ) sulfat atau (U, Th, LTJ) nitrat ini kemudian langsung digunakan untuk tahap selanjutnya yaitu proses ekstraksi untuk pengambilan $U$ dan Th. Akan tetapi pelarutan dengan asam selain $\mathrm{HCl}$ tersebut memerlukan konsumsi asam yang lebih banyak. Pelarutan dengan $\mathrm{H}_{2} \mathrm{SO}_{4}$ diperlukan jumlah asam 2-3 kali jumlah $\mathrm{HCl}$. Di samping itu, kelarutan (U, Th, LTJ) hidroksida dalam $\mathrm{H}_{2} \mathrm{SO}_{4}$ 1ebih kecil dibandingkan dengan $\mathrm{HCl}$ [8]. Reaksi yang terjadi pada proses pelarutan (U, Th, LTJ) hidroksida dengan $\mathrm{HCl}$ adalah sebagai berikut [1]:

$$
\begin{aligned}
& \mathrm{LTJ}(\mathrm{OH})_{3}(\mathrm{~s})+3 \mathrm{HCl}(\mathrm{aq}) \rightarrow \mathrm{LTJCl}_{3}(\mathrm{aq})+ \\
& 3 \mathrm{H}_{2} \mathrm{O}(\mathrm{aq}) \\
& \mathrm{Th}(\mathrm{OH})_{4}(\mathrm{~s})+4 \mathrm{HCl}(\mathrm{aq}) \rightarrow \mathrm{ThCl}_{4}(\mathrm{aq})+ \\
& 4 \mathrm{H}_{2} \mathrm{O}(\mathrm{aq}) \\
& \mathrm{UO}_{2}(\mathrm{OH})_{2}(\mathrm{~s})+2 \mathrm{HCl}(\mathrm{aq}) \rightarrow \mathrm{UO}_{2} \mathrm{Cl}_{2}(\mathrm{aq})+ \\
& 2 \mathrm{H}_{2} \mathrm{O}(\mathrm{aq})
\end{aligned}
$$

Metode pengendapan bertingkat merupakan salah satu metode pemisahan untuk mendapatkan unsur logam tanah jarang. Umumnya proses ini dilakukan dengan menambahkan hidroksida sehingga akan menghasilkan endapan dalam bentuk senyawa hidroksida. Prinsip dasarnya adalah perbedaan tetapan hasil kali kelarutan (Ksp) unsur dalam bentuk hidroksidanya. Pengendapan ini terjadi karena zat tersebut berada dalam bentuk persenyawaan, yaitu hasil kali konsentrasi ion-ionnya melebihi harga Ksp senyawa tersebut. Ksp atau hasil kali kelarutan adalah hasil kali konsentrasi ion-ion dalam larutan jenuh pada suhu tertentu, setelah masing-masing konsentrasi dipangkatkan dengan koefisiennya menurut persamaan ionisasinya [9]. Pemisahan dengan metode pengendapan bertingkat juga dilakukan dengan menambahkan hidroksida untuk memperoleh hasil pemisahan yang lebih selektif [10]. Selama pengendapan unsur-unsur dalam monasit akan bereaksi dengan basa sebagai berikut [8]:

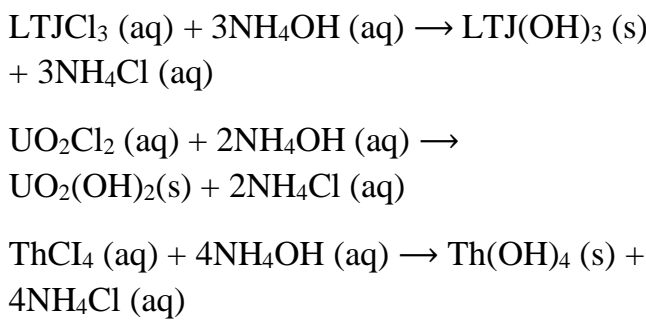

\section{METODOLOGI}

\section{Alat dan Bahan}

Bahan yang digunakan pada penelitian ini antara lain monasit Bangka ukuran butiran $44 \mu \mathrm{m}$, aquades, natrium hidroksida, asam klorida pekat teknis $14 \mathrm{~N}$, ammonium hidroksida teknis, dan bahan kimia analisis. Alat yang digunakan adalah motor pengaduk, statif, termometer, vakum, cawan petri, kertas saring whattman, lemari asam, hot plate, labu ukur, $\mathrm{pH}$ meter, oven, furnace, mortar, ayakan 325 mesh, timbangan analitik, Spektrofotometer UV-Vis Shimadzu 2600, dan ICP-OES Perkin Elmer.

\section{Metode}

Proses pembuatan umpan untuk pengendapan bertingkat diawali dengan dekomposisi monasit menggunakan $\mathrm{NaOH}$ untuk memutus ikatan fosfat sehingga akan menghasilkan endapan hidroksida [11]. Selanjutnya, endapan hidroksida hasil proses dekomposisi dilarutkan dengan $\mathrm{HCl}$ pekat 14 $\mathrm{N}$ dengan perbandingan endapan hidroksida : 
$\mathrm{HCl}=1: 1$. Proses ini dijaga pada suhu $80^{\circ} \mathrm{C}$ selama 2 jam sehingga $\mathrm{HCl}$ dapat melarutkan lebih dari $80 \%$ endapan. Slurry hasil pelarutan dipisahkan filtrat dan residunya melalui penyaringan vakum. Kadar U dan Th pada filtrat hasil penyaringan dianalisis dengan spektrofotometer UV-Vis sedangkan kadar LTJ dan unsur minor (pengotor), antara lain $\mathrm{Al}, \mathrm{Fe}, \mathrm{Bi}, \mathrm{Ga}$, dan $\mathrm{Tl}$, dianalisis menggunakan ICP-OES. Filtrat ini merupakan umpan proses pengendapan bertingkat.

Pada proses pengendapan bertingkat, filtrat hasil pelarutan sebanyak $300 \mathrm{ml}$ diendapkan dengan reagen $\mathrm{NH}_{4} \mathrm{OH}$. Proses pengendapan ini menggunakan variasi $\mathrm{pH}$ sebanyak 20, antara lain dimulai dari $\mathrm{pH} 0,5$; $1 ; 1,5 ; 2 ; 2,5 ; 3 ; 3,5 ; 4 ; 4,5 ; 5 ; 5,5 ; 6 ; 6,5 ; 7$; 7,$5 ; 8 ; 8,5 ; 9 ; 9,5 ;$ dan 10. Penambahan $\mathrm{NH}_{4} \mathrm{OH}$ dihentikan apabila $\mathrm{pH}$ yang diinginkan telah tercapai dan larutan didiamkan selama 1 jam pada suhu kamar hingga menghasilkan endapan. Endapan yang dihasilkan kemudian dipisahkan melalui proses penyaringan menggunakan corong dan kertas saring. Selanjutnya filtrat hasil penyaringan tersebut diendapkan kembali dengan $\mathrm{NH}_{4} \mathrm{OH}$ sesuai $\mathrm{pH}$ yang diinginkan. Begitu seterusnya sampai variasi $\mathrm{pH}$ terakhir. Endapan yang dihasilkan dari setiap pengendapan dianalisis dengan spektrofotometer UV-Vis dan ICP-OES.

\section{HASIL DAN PEMBAHASAN}

Pengendapan bertingkat dilakukan secara bertahap dengan mengatur $\mathrm{pH}$ sesuai yang diinginkan dengan umpan yang sama. Reagen yang digunakan untuk mengendapkan unsur $\mathrm{U}$, Th, LTJ, serta pengotor adalah $\mathrm{NH}_{4} \mathrm{OH}$ sebagai senyawa hidroksida yang akan mengikat unsur klorida pada filtrat pelarutan sebagai umpan proses ini dan membentuk $\mathrm{NH}_{4} \mathrm{Cl}$ pada fase cair serta endapan hidroksida pada fase padat, seperti persamaan reaksi (7), (8) dan (9).

Penelitian ini menggunakan pengendapan bertingkat dengan variasi $\mathrm{pH}$ dimulai dari 0,5 sampai 10 dengan rentang antar-pH adalah 0,5. Endapan dihasilkan pada $\mathrm{pH} 3 ; 6 ; 6,5$ dan 7. Selain keempat $\mathrm{pH}$ tersebut, endapan tidak terbentuk pada $\mathrm{pH}$ lainnya.

Variasi $\mathrm{pH}$ yang dilakukan menghasilkan empat endapan seperti yang dapat dilihat pada Tabel 1 di bawah ini beserta jumlah $\mathrm{NH}_{4} \mathrm{OH}$ yang digunakan. Endapan paling akhir terbentuk pada $\mathrm{pH} 7$ dan pada $\mathrm{pH}$ selanjutnya sampai $\mathrm{pH} 10$, yaitu variasi $\mathrm{pH}$ paling terakhir pada proses ini sudah tidak terbentuk endapan lagi.

Tabel 1. Berat endapan dan jumlah $\mathrm{NH}_{4} \mathrm{OH}$ yang digunakan.

\begin{tabular}{ccc}
\hline pH & $\begin{array}{c}\text { Berat endapan } \\
(\mathbf{g})\end{array}$ & $\begin{array}{c}\text { Jumlah NH4OH } \\
(\mathbf{m l})\end{array}$ \\
\hline $\mathrm{pH} \mathrm{3}$ & 25,574 & 53 \\
$\mathrm{pH} \mathrm{6}$ & 26,27 & 90,2 \\
$\mathrm{pH} \mathrm{6,5}$ & 24,92 & 98,4 \\
$\mathrm{pH} \mathrm{7}$ & 12,43 & 112,9 \\
\hline Total & 89,194 & 354,5 \\
\hline
\end{tabular}

Berat endapan yang dihasilkan berbedabeda begitu juga konsumsi $\mathrm{NH}_{4} \mathrm{OH}$ seperti yang terlihat pada Tabel 1. Umpan yang digunakan sebanyak $300 \mathrm{ml}$. Endapan yang paling banyak, yaitu endapan pada $\mathrm{pH} 6$ dengan konsumsi $\mathrm{NH}_{4} \mathrm{OH}$ sebanyak 90,24 ml. Hal ini menandakan banyaknya unsur yang dapat mengendap pada $\mathrm{pH}$ tersebut. Endapan pH 3 hanya butuh $53 \mathrm{ml} \mathrm{NH}_{4} \mathrm{OH}$ untuk menghasilkan berat endapan sedikit lebih kecil dari endapan pH 6. Hal ini disebabkan oleh banyaknya jumlah unsur-unsur yang memang dapat mengendap pada $\mathrm{pH} 3$ sehingga dengan konsumsi $\mathrm{NH}_{4} \mathrm{OH}$ sedikit sudah dapat berinteraksi membentuk endapan.

Konsumsi $\mathrm{NH}_{4} \mathrm{OH}$ paling banyak pada endapan $\mathrm{pH}$ 6,5 dan berat endapan yang 
dihasilkan lebih sedikit dibandingkan endapan $\mathrm{pH} 3$ dan $\mathrm{pH}$ 6. Masih terbentuknya endapan pada $\mathrm{pH}$ 6,5 dan $\mathrm{pH} 7$ karena waktu pengendapan yang relatif sebentar sehingga di dalam umpan masih ada unsur-unsur yang belum terendapkan dan dapat mengendap di $\mathrm{pH}$ berikutnya [12]. Berat endapan semakin sedikit seiring dengan bertambahnya $\mathrm{pH}$. Hal ini dikarenakan unsur-unsur tersebut sudah banyak mengendap di $\mathrm{pH}$ sebelumnya.

Endapan mulai terbentuk pada $\mathrm{pH} 3$ karena pada $\mathrm{pH}$ tersebut mulai terjadi interaksi antara unsur-unsur di dalam umpan dengan pereaksi. Hasil reaksi antara unsur dengan $\mathrm{NH}_{4} \mathrm{OH}$ akan menghasilkan garam amonium klorida, selain unsur itu sendiri dalam bentuk hidroksidanya [13]. Torium berada dalam bentuk hidroksidanya pada $\mathrm{pH}$ $>2$ dan logam tanah jarang pada $\mathrm{pH}>6,5$ [14].

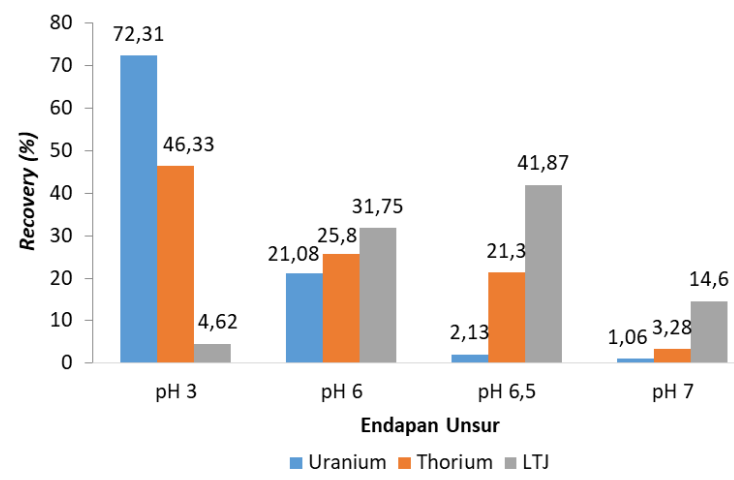

Gambar 1. Recovery pengendapan bertingkat unsur U, Th, dan LTJ .

Endapan pertama terbentuk pada $\mathrm{pH} 3$ dengan recovery uranium $72,31 \%$, disusul oleh torium 46,33\%, dan LTJ 4,62\% (Gambar 1). Penelitian yang dilakukan oleh PTBGNBATAN telah mendapatkan kondisi optimal untuk pengendapan $U$ dan Th melalui proses pengolahan basa yaitu pada $\mathrm{pH}$ 6,3 [2]. Kondisi optimal tersebut menunjukkan unsur uranium dan torium banyak mengendap pada $\mathrm{pH}$ 6,3 tetapi tidak menutup kemungkinan pada $\mathrm{pH}$ yang lebih rendah dari itu uranium dan torium sudah dapat terendapkan. Pengendapan uranium dengan pereaksi $\mathrm{NH}_{4} \mathrm{OH}$ dapat terjadi pada $\mathrm{pH}$ yang lebih rendah dari $\mathrm{pH}$ optimalnya karena terbentuknya garam amonium klorida yang dapat memperkecil nilai $\mathrm{pH}$ pengendapan [13]. Nilai Ksp uranium dalam bentuk hidroksidanya, yaitu $\mathrm{UO}_{2}(\mathrm{OH})_{2}$ sebesar $1,1 \times 10^{-22}[15]$.

Torium mulai mengendap pada $\mathrm{pH} 2,3$ berdasarkan perhitungan teori menggunakan nilai $\mathrm{Ksp} \mathrm{Th}(\mathrm{OH})_{4}$ sebesar $10^{-55,7}$ [15] tetapi pada penelitian ini torium mulai mengendap pada $\mathrm{pH}$ 3. Nilai Ksp uranium dan torium jika direaksikan dengan reagen basa adalah rendah. Semakin rendah nilai Ksp maka unsur tersebut lebih mudah mengendap [16].

Endapan pada pH 6 memiliki nilai recovery uranium sebesar $21,08 \%$, torium $25,8 \%$, dan logam tanah jarang $31,75 \%$. Nilai recovery uranium dan torium lebih kecil dibandingkan endapan pada $\mathrm{pH} 3$ karena unsur tersebut sudah banyak mengendap pada $\mathrm{pH} 3$ tetapi masih dapat mengendap di $\mathrm{pH}$ yang lebih tinggi dari 3 . Uranium dan torium optimal mengendap pada $\mathrm{pH}$ 6,3 [2].

Endapan pada $\mathrm{pH}$ 6,5 nilai recovery uraniumnya sudah sedikit, yaitu $2,13 \%$ sedangkan toriumnya masih sebesar $21,3 \%$, tidak jauh dari endapan pada $\mathrm{pH}$ 6. Masih adanya torium pada $\mathrm{pH}$ 6,5 berkaitan dengan $\mathrm{pH}$ optimum pengendapan torium itu sendiri. Nilai recovery LTJ pada $\mathrm{pH}$ 6,5 adalah yang paling banyak dibandingkan yang lainnya. Hal ini berkaitan dengan sifat LTJ itu sendiri yang mulai mengendap pada $\mathrm{pH}>6,5$ [14].

Endapan pada pH 7 memiliki nilai recovery uranium dan torium paling kecil dibandingkan endapan lainnya tetapi untuk LTJ masih cukup banyak dibandingkan pada $\mathrm{pH}$ 3. Kandungan uranium dan torium lebih sedikit karena kedua unsur itu telah banyak 
mengendap di $\mathrm{pH}$ sebelumnya dan memang kedua unsur itu mulai mengendap pada $\mathrm{pH}$ yang lebih rendah. LTJ sendiri memiliki nilai sebesar $14,6 \%$ karena masih dapat mengendap pada $\mathrm{pH}$ tinggi.

Nilai pKsp LTJ yang berkisar antara 2224 menunjukkan semua LTJ mengendap pada pH tinggi [17]. Nilai pKsp semakin kecil atau semakin besar harga Ksp, konsentrasi $\mathrm{OH}^{-}$ semakin besar dan nilai $\mathrm{pOH}$ semakin kecil sehingga nilai $\mathrm{pH}$ untuk mengendapkan LTJ semakin besar [18].

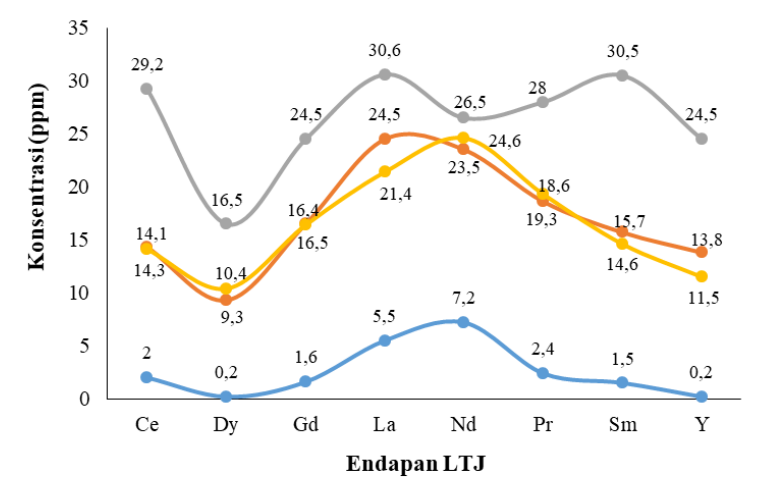

$\multimap$ Endapan pH $3 \multimap$ Endapan pH $6 \multimap$ Endapan pH 6,5 $\multimap$ Endapan pH 7

Gambar 2. Konsentrasi LTJ pada tiap endapan pada pengendapan bertingkat.

Monasit mengandung LTJ ringan seperti La, Ce, Nd, dan Pr kurang lebih 90\% serta sedikit Y dan LTJ, berat antara lain Gd dan Dy [5]. Dari Gambar 2 terlihat unsur Nd dan La mendominasi komposisi LTJ di setiap endapan yang dihasilkan, kecuali pada endapan $\mathrm{pH}$ 6,5, La digantikan oleh $\mathrm{Sm}$. Unsur yang paling sedikit pada setiap endapan adalah Y dan Dy. Logam Y dan Dy mulai mengendap pada $\mathrm{pH} 8,14$ dan 8,18. Rata-rata $\mathrm{pH}$ untuk mengendapkan logam tanah jarang adalah $\mathrm{pH} 8$ tetapi ada juga pada pH 7 [17]. Logam tanah jarang mulai mengendap pada $\mathrm{pH} 3$ dengan kadar yang paling sedikit dibandingkan dengan $\mathrm{U}$ dan $\mathrm{Th}$. Penelitian terdahulu telah menghasilkan logam La, Ce, dan Nd sebagai LTJ yang paling banyak pada proses pengendapan bertingkat residu digesti monasit [4]. Ketiga logam tersebut mulai mengendap pada $\mathrm{pH}$ 0,45 . Variasi $\mathrm{pH}$ yang dilakukan mulai dari 0,45 sampai 0,9 dengan selisih 0,05 antarsetiap $\mathrm{pH}$.

Pada Penelitian lainnya, proses mengendapkan LTJ dari filtrat pelarutan monasit dengan asam menggunakan dinatrium oksalat telah menghasilkan LTJ $\mathrm{Sm}, \mathrm{Pr}, \mathrm{Nd}, \mathrm{Ce}$, dan $\mathrm{La}$ yang mulai mengendap pada $\mathrm{pH}<1$ [19]. Persentase LTJ yang rendah dihasilkan pada $\mathrm{pH}$ yang paling rendah, kemudian mengalami kenaikan seiring bertambahnya $\mathrm{pH}$. Hal ini sejalan dengan penelitian, yaitu LTJ dapat mengendap pada $\mathrm{pH}$ rendah tetapi dalam persentase perolehan yang sedikit. Kenaikan pH mengakibatkan kenaikan jumlah LTJ yang terendapkan.

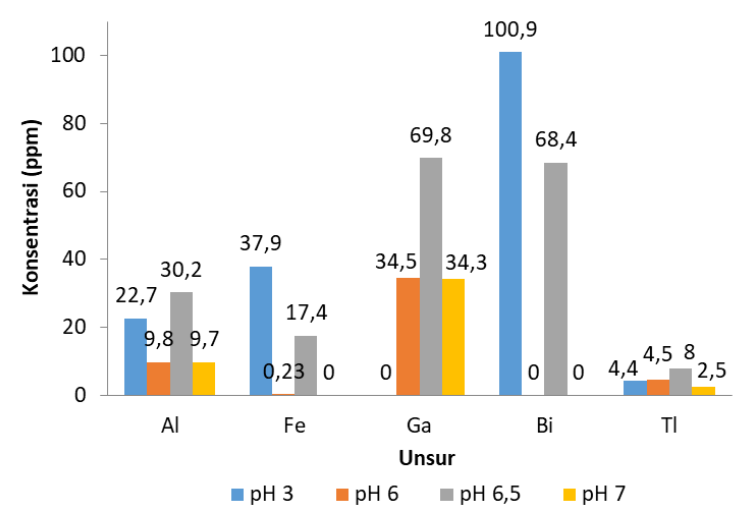

Gambar 3. Konsentrasi unsur pengotor pada tiap endapan pada pengendapan bertingkat.

Selain LTJ, U, dan Th, penelitian pengendapan bertingkat ini juga mengendapkan unsur pengotor. Seperti terlihat pada Gambar 3, unsur pengotor yang dominan dan terdeteksi dengan alat analisis ICP-OES adalah Al, Fe, Ga, Bi, dan Tl. Unsur Fe dan Bi paling banyak mengendap pada $\mathrm{pH}$ 3 dengan kadar 37,9 ppm dan 100,9 ppm. Unsur $\mathrm{Al}, \mathrm{Ga}$, dan $\mathrm{Tl}$ paling banyak mengendap pada $\mathrm{pH}$ 6,5 dengan kadar 30,2 ppm, 69,8 ppm, dan 8 ppm.

Unsur pengotor mengendap pada pHnya masing-masing didasarkan nilai Ksp dan 
pKsp-nya [20]. Nilai Ksp unsur Al dalam bentuk hidroksidanya setelah bereaksi dengan $\mathrm{NH}_{4} \mathrm{OH}$ seperti reaksi di bawah ini adalah 1,8 $\times 10^{-33}[21]$ :

$$
\begin{aligned}
& \mathrm{Al}(\mathrm{OH}) 3(\mathrm{~s})+3 \mathrm{HCl}(\mathrm{aq}) \rightarrow \mathrm{AlCl} 3(\mathrm{aq})+ \\
& 3 \mathrm{H} 2 \mathrm{O}(\mathrm{aq}) \\
& \mathrm{AlCl} 3(\mathrm{aq})+3 \mathrm{NH} 4 \mathrm{OH}(\mathrm{aq}) \rightarrow \mathrm{Al}(\mathrm{OH}) 3(\mathrm{~s})+ \\
& 3 \mathrm{NH} 4 \mathrm{Cl}(\mathrm{aq})
\end{aligned}
$$

Nilai Ksp Al cukup kecil artinya pKsp-nya besar dan berdasarkan perhitungan teori $\mathrm{pH}$ untuk mengendapkan $\mathrm{Al}(\mathrm{OH})_{3}$ adalah 3. Nilai $\mathrm{pH}$ tersebut menunjukkan unsur $\mathrm{Al}$ dalam larutan $\mathrm{HCl}$ yang berinteraksi dengan $\mathrm{NH}_{4} \mathrm{OH}$ dapat mengendap pada $\mathrm{pH}$ tersebut membentuk endapan $\mathrm{Al}(\mathrm{OH})_{3}$. Unsur $\mathrm{Al}$ berdasarkan percobaan mulai mengendap pada $\mathrm{pH} 3$ sesuai dengan perhitungan yang telah dibuat. Unsur ini juga terbentuk pada $\mathrm{pH}$ lainnya dan paling banyak pada endapan $\mathrm{pH} 6,5$.

Nilai Ksp unsur Fe untuk membentuk endapan $\mathrm{Fe}(\mathrm{OH})_{3}$ adalah $1,1 \times 10^{-36}$ [21]. Nilai $\mathrm{pH} \mathrm{Fe}(\mathrm{OH})_{3}$ berdasarkan perhitungan teori untuk dapat mengendap adalah 3,2. Penelitian ini menghasilkan unsur $\mathrm{Fe}$ pada endapan pH 3 dan 6,5. Hal ini menunjukkan Fe mulai terbentuk pada $\mathrm{pH} 3$ sesuai dengan perhitungan teorinya. $\mathrm{Fe}$ juga mengendap pada $\mathrm{pH}$ yang lebih tinggi, yaitu 6,5 tetapi tidak ada pada $\mathrm{pH} 6$ dan 7. Unsur Fe telah habis mengendap pada endapan $\mathrm{pH}$ 6,5 sehingga pada $\mathrm{pH}$ yang lebih tinggi tidak terbentuk lagi. Unsur $\mathrm{Fe}$ paling banyak ada pada endapan $\mathrm{pH}$ 3. Berbeda dengan penelitian yang dilakukan sebelumnya [19] yang mengendapkan unsur pengotor dari filtrat pelarutan monasit dengan asam menggunakan dinatrium oksalat menghasilkan endapan unsur pengotor berupa $\mathrm{Al}, \mathrm{Fe}, \mathrm{Pb}, \mathrm{Ca}$, dan $\mathrm{Cu}$. Pada endapan tersebut Al paling besar kadarnya dan paling banyak mengendap pada $\mathrm{pH}$ 3. Unsur Fe paling banyak mengendap pada $\mathrm{pH}$ 5. Perbedaan ini diduga karena penggunaan reagen pengendap yang tidak sama, yaitu $\mathrm{NH}_{4} \mathrm{OH}$ dan dinatrium oksalat sehingga unsur yang mengendap berbeda pada $\mathrm{pH}$ yang sama.

\section{KESIMPULAN}

Berdasarkan hasil penelitian, variasi $\mathrm{pH}$ pada pengendapan bertingkat pengolahan monasit menghasilkan endapan pada $\mathrm{pH} 3$, $\mathrm{pH}$ 6, pH 6,5, dan $\mathrm{pH}$ 7. Unsur uranium dan torium paling banyak mengendap pada $\mathrm{pH} 3$ dengan recovery $\mathrm{U} 72,3 \%$ dan $\mathrm{Th} 46,33 \%$ serta LTJ pada $\mathrm{pH}$ 6,5 dengan recovery 41,87\%. Unsur $\mathrm{Fe}$ dan $\mathrm{Bi}$ paling banyak mengendap pada $\mathrm{pH} 3$ dengan kadar 37,9 ppm dan 100,9 ppm. Unsur Al, Ga, dan Tl paling banyak mengendap pada $\mathrm{pH} 6,5$ dengan kadar 30,2 ppm, 69,8 ppm, dan 8 ppm. Dengan mengetahui kondisi $\mathrm{pH}$ pengendapan unsur pengotor pada monasit diharapkan akan diperoleh produk LTJ, U, dan Th dengan kemurnian yang lebih tinggi.

\section{UCAPAN TERIMA KASIH}

Penulis menyampaikan terimakasih khususnya kepada seluruh staf Bidang Teknologi Penambangan dan Pengolahan serta PTBGN-BATAN pada umumnya yang telah mendukung jalannya penelitian. Terimakasih kepada Ibu Budi Yuli Ani yang telah membantu proses penelitian di laboratorium pengolahan, Ibu Ersina Rakhma, Bapak Afiq Azfar Pratama, dan Kak Yoga Permana yang telah membantu proses analisis sampel dengan XRF, ICP-OES, dan Spektrofotometer UV-Vis, serta kepada PT Timah (Persero) Tbk. yang telah menyediakan monasit sebagai bahan baku pada penelitian ini. 


\section{DAFTAR PUSTAKA}

[1] Sumarni, R. Prassanti, K. Trinopiawan, Sumiarti, dan H. L. Nuri, "Penentuan Kondisi Pelarutan Residu dari Hasil Pelarutan Parsial Monasit Bangka," Eksplorium, vol. 32, no. 2, hal. 115124, 2011, doi: http://dx.doi.org/10.17146/ eksplorium.2011.32.2.2819.

[2] R. Prassanti, "Digesti Monasit Bangka dengan Asam Sulfat," Eksplorium, vol. 33, no. 1, hal. 4154, 2012, doi: http://dx.doi.org/10.17146/ eksplorium.2012.33.1.676.

[3] Sumarni, E. RA, F. Riza, Tukardi, Tarjudin, dan Rusydi, "Pelarutan Residu Hasil Dekomposisi Bijih Uranium Rirang," Pros. Semin. Geol. Nukl. dan Sumber Daya Tambang Tahun 2004 Pus. Pengemb. Bahan Galian dan Geol. Nukl. BATAN, vol. 85, hal. 299-304, 2004

[4] S. Suyanti dan M. V Purwani, "Pengendapan Torium dari Hasil Olah Pasir Monasit," Pros. Pertem. dan Present. Ilm. Penelit. Dasar Ilmu Pengetah. dan Teknol. Nukl., hal. 147-154, 2011.

[5] G. K. Gupta dan N. Krishnamurthy, Extractive Metallurgy of Rare Earths, vol. 37, no. 1. 1992.

[6] Suyono, A. Supriyadi, A. W. Kencono, dan B. E. Prasetyo, Kajian Potensi Mineral Ikutan pada Pertambangan Timah. Jakarta: Pusat Data dan Teknologi Informasi Energi dan Sumber Daya Mineral, 2017.

[7] F. P. Sagala, Adiwardoyo, dan E. M. Parmanto, Model Atom, Uranium dan Prospeknya sebagai Energi Masa Depan. Jakarta: Badan Tenaga Nuklir Nasional, Pusat Diseminasi Iptek Nuklir, 2003.

[8] H. L. Nuri, F. Riza, S. Waluyo, B. Sarono, Mukhlis, dan Sumarni, "Pelarutan (U, Th, RE) Hidroksida Hasil Dekomposisi Basa Monasit Bangka dengan Menggunakan Asam Nitrat," Semin. IPTEK Nukl. dan Pengelolaan Sumber Daya Tambang, hal. 144-150, 2002.

[9] C. W. Keenan, Kimia Untuk Universitas, 1 ed. Jakarta: Erlangga, 1992.

[10] J. E. Huheey, Inorganic Chemistry, 4th ed. New York: Harper International, 1993.

[11] R. Prassanti, D. S. Putra, B. P. Kusuma, dan F. W. Nawawi, "Analysis of the Effects of Stirring
Condition of Separation of Thorium in the Elution Process of Monazite Partial Solution by Solvent Impregnated Resin Method," IOP Conf. Ser. Mater. Sci. Eng., vol. 303, no. 1, hal. 1-6, 2018, doi: 10.1088/1757-899X/303/1/012005.

[12] K. Trinopiawan dan Sumiarti, "Pemisahan Thorium dari Uranium pada Monasit dengan Metode Pengendapan," Eksplorium, vol. 33, no. 1, hal. 55-62, 2012.

[13] Torowati, "Pengaruh Kandungan Uranium dalam Umpan Terhadap Efisiensi Pengendapan Uranium," J. Pus. Teknol. Bahan Bakar Nukl., hal. 9-15, 2010.

[14] R. Subagja, "Monasit Bangka dan Alternatif Proses Pengolahannya," J. Metal., vol. 29.1, hal. 79-90, 2014.

[15] S. Syarip dan S. Widodo, Dari Pasir Monasit ke Torium: Bahan Baku Bahan Bakar Nuklir dan Radioisotop Medik. Yogyakarta: Pustaka Pelajar, 2019.

[16] M. Anggraini, B. Sarono, dan S. Waluyo, "Uranium and Thorium Precipitation from Solution of Tin Slag II," Eksplorium, vol. 36, no. 2, hal. 125-132, 2015.

[17] F. A. Cotton dan G. Wilkinson, Kimia Anorganik Dasar. Jakarta: Universitas Indonesia (UI Press), 1989.

[18] Suyanti, M. V Purwani, dan A. Muhadi, "Peningkatan Kadar Neodimium Secara Proses Pengendapan Bertingkat Memakai Amonia," Pus. Teknol. Akselerator dan Proses Bahan-BATAN, hal. 429-438, 2008.

[19] A. Kumari, S. Jha, J. Narayan, S. Chakravarty, dan M. Kumar, "Processing of Monazite Leach Liquor for the Recovery of Light Rare Earth Metals ( LREMs )," Miner. Eng., vol. 129, no. July, hal. 9-14, 2018, doi: 10.1016/j.mineng. 2018.09.008.

[20] R. Prassanti, B. Y. Ani, S. Sumiarti, dan E. Dewita, "Pengendapan Torium (Th) dari Monasit Bangka Setelah Proses Solvent Impregnated Resin (SIR)," Eksplorium, vol. 40, no. 2, hal. 127, 2019, doi: 10.17146/eksplorium.2019.40.2.5648.

[21] R. Chang, Kimia Dasar Jilid 2, 2 ed. Jakarta: Erlangga, 2006. 